\title{
PENGARUH MODEL PEMBELAJARANINQUIRYTRAINING \\ BERBASIS KOLABORATIF TERHADAP KETERAMPILAN \\ PROSES SAINS MATERI SUMBER DAYA ALAM DI SD METHODIST 1 MEDAN
}

\section{OLEH:}

\section{DYAN WULAN SARI HS ${ }^{1}$, AGUS KISTIAN ${ }^{2}$ \\ (UNIVERSITAS KATOLIK SANTO THOMAS MEDAN ${ }^{1}$, STKIP BINA BANGSA MEULABOH)}

\begin{abstract}
This study aimed to analyze. The Influence of learning model on students science process skill. This study is a quasi-experimental research (quasi experiment). The population of this research is fourth grade students of SD Methodist 1 Medan. The sample in this study selected by purposive random sampling as much as two gradtahun es. Class experiment treated with a inquiry training model based collaborative, the control class treated with direct instruction model. The instrument used consisted of: science process skill test and scientific attitude questionnaire sheet. Data analysis was performed using ANOVA two lanes. The results of this study indicate that: (1) the process of science students that learned Science with learning inquiry training model based collaborative is higher than direct instruction; (2) Science process skill students with high scientific attitudes indicates is higher than low scientific attitudes; and (3) an interaction between the inquiry training model based collaborative and direct instruction with the level of scientific attitudes in influencing student science process skills. The results of this research suggest that the learning model inquiry training based collaborative is a solution to and alternatives for the teachers to improve student science process skills.
\end{abstract}

Keywords: Science Process Skill, Scientific Attitude, Inquiry Training, Creativity, The Natural Resources, Collaborative

\section{PENDAHULUAN}

\section{Latar Belakang Masalah}

Pendidikan merupakan salah satu usaha untukmencerdaskan kehidupan bangsa dan merupakan suatukunci pokok untuk mencapai cita-cita suatu bangsa.Pendidikan diyakini akan dapat mendorongmemaksimalkan potensi siswa sebagai calon sumber dayayang handal untuk dapat bersikap kritis, logis, 
daninovatif dalam menghadapi dan menyelesaikan setiappermasalahan yang dihadapi. Pendidikan menuntutadanya perbaikan yang terus menerus. Pendidikan tidakhanya ditekankan pada penguasaan materi, tetapi jugaditekankan pada penguasaan keterampilan. Pendidikan yang mampu mendukung pembangunan di masa mendatang adalah pendidikan yang mampu mengembangkan potensi nurani maupun potensi kompetensi peserta didik. Oleh karena itu, program pendidikan dan pembelajaran saat ini harus lebih diarahkan atau lebih berorientasi kepada individu peserta didik. Amri (2010) mengemukakan bahwa "Pendidikan tidak mengharapkan muncul manusia-manusia yang menjadi terasing dari lingkungan masyarakatnya, tetapi justru melalui pendidikan diharapkan dapat lebih mengerti dan mampu membangun kehidupan masyarakatnya”. Oleh karena itu tujuan, isi, maupun proses pendidikan harus disesuaikan dengan kebutuhan, kondisi, karakteristik kekayaan dan perkembangan yang ada di masyarakat.

Salah satu upaya peningkatan kualitas pendidikan tersebut adalah mengubahkan paradigma pendidikan khususnya di Sekolah Dasar (SD) dari pembelajaran yang berpusat pada guru (teacher centered) ke arah pembelajaran yang berpusat pada siswa (student centered). Hal ini menuntut setiap guru untuk lebih kreatif dalam mengembangkan pembelajaran, sehingga memungkinkan siswa dapat berprestasi melalui kegiatan-kegiatan nyata yang menyenangkan dan mampu mengembangkan potensi dirinya secara optimal. Dalam proses pembelajaran setiap guru senantiasa mengharapkan agar siswanya dapat memahami konsep dari materi yang diajarkan serta mencapai hasil belajar yang sebaik-baiknya. 
Pendidikan IPA (sains) adalah salah satu aspek pendidikan yang digunakan sebagai alat untuk mencapai tujuan pendidikan. Menurut Departemen Pendidikan Nasional (2003) menyebutkan bahwa pendidikan sains tersebut tidak hanya terdiri dari fakta,konsep,teori yang dapat dihafalkan, tetapi juga terdiri atas kegiatan atau proses aktif menggunakan pikiran dan sikap ilmiah dalam mempelajari gejala alam yang belum diterangkan. Dengan demikian, tuntutan untuk terus-menerus memutahirkan sains menjadi suatu keharusan. Peranan pendidikan IPA (sains) menekankan pada pemberian pengalaman langsung untuk mengembangkan kompetensi agar siswa mampu menjelajahi dan memahami alam sekitar secara ilmiah. Pendidikan sains diarahkan untuk "mencari tahu" dan “berbuat” sehingga dapat membantu siswa untuk mengetahui alam labih dalam.

Dalam membelajarkan mata pelajaran Sains di Sekolah Dasar (SD) tentunya akan menjadi suatu hal yang sangat menarik, mengingat bahwa usia Sekolah Dasar merupakan masa yang penting bagi anak dalam membentuk pengetahuan dasarnya melalui pengalaman yang dialaminya baik di sekolah maupun di lingkungan tempat tinggalnya, artinya sangatlah penting untuk menanamkan dasar-dasar keilmuan dengan sangat baik dan bermakna guna memperoleh pondasi yang kuat dalam menguasai materi pelajaran. Mata Pelajaran Sains di SD jika disajikan dengan model pembelajaran yang tidak tepat maka tentunya akan menjadi kendala bagi siswa dalam mengembangkan pengetahuan yang dimilikinya.

Fakta yang diperoleh di lapangan tidak sesuai dengan harapan, dimana pembelajaran IPA yang diterapkan belum menggunakan model pembelajaran 
yang tepat dalam membelajarkannya, beberapa diantaranya hanya dibelajarkan dengan metode tradisional yang berpusat pada guru, dan didominasi oleh mencatat dan pengerjaan soal latihan atau sering disebut dengan Direct Instruction (DI).

Siswa membutuhkan guru yang tidak lagi menggunakan modeldirect instruction. Dimana guru IPA yang khususnya mengajar di tingkat SD sudah saatnya merancang suatu pendekatan yang dapat menciptakan suasana belajar yang mampu meningkatkan keaktifan siswa di dalam kelas. Hal ini sejalan dengan pernyataan Azizah\&Parmin (2012) bahwa siswa diberikan kesempatan lebih aktif dalam menggali dan mengkontruksi pengetahuannya melalui lingkungan sekitar.

Dibutuhkan suatu pembelajaran yang tidak lagi menggunakan model direct instruction. Dimana guru IPA khusunya untuk guru SD harus dituntut dalam merancang suatu model pembelajaran yang dapat menciptakan suasana belajar yang mampu meningkatkan keaktifan siswa di dalam kelas. Hal ini sejalan dengan pernyataan Azizah\&Parmin (2012) bahwa peserta didik diberikan kesempatan lebih aktif dalam menggali dan mengkonstruksi pengetahuannya melalui lingkungan sekitar. Berdasarkan hasil observasi peneliti awal juga sekitar 80\% siswa kelas IV mengalami kesulitan belajar IPA. Hal ini terlihat bahwa ketuntasan yang dicapai siswa pada semester I belum mencapai standar ketuntasan belajar minal yang ditentukan oleh sekolah yaitu 65 , sementara nilai yang dicapai oleh siswa berkisar antara 50 sampai dengan 60 . Rendahnya pemahaman siswa terhadap materi pelajaran diduga disebabkan oleh kegiatan pembelajaran selama ini, siswa hanya bertindak pasif menerima informasi tanpa mengalaminya sendiri, siswa kurang aktif bertanya. Ketika guru menjelaskan materi yang diajarkan, 
bertanya kepada siswa siapa yang ingin mengajukan pertanyaan terkait materi yang diberikan oleh guru tersebut, ternyata siswa kurang merespon, siswa cenderung hanya memperhatikan guru menjelaskan, namun enggan untuk bertanya. Hal ini mengindikasi bahwa kemampuan meneliti siswa masih relatif rendah. Karena siswa belum aktif bertanya mengenai materi yang disampaikan guru. Bertanya merupakan salah satu komponen keterampilan dalam meneliti. Selain itu, siswa juga menganggap mata pelajaran IPA adalah mata pelajaran yang sulit untuk dimengerti karena banyak hal-hal yang tidak bisa dilihat secara langsung. Pembelajaran juga masih bersifat ekspositori maksudnya guru menjelaskan terhadap materi kepada siswa tanpa ada proses dalam memahami suatu konsep. Selain itu terlihat juga siswa belajar lebih individual maksudnya siswa yang memiliki prestasi tidak mau membantu temannya dan siswa yang kurang faham merasa malu untuk bertanya kepada yang lebih faham. Belajar berkolaboratif memiliki manfaat karena siswa menjadi lebih paham dengan bahasa sederhana dan tanpa ada batasan.Kolaboratif merupakan pengajaran bekerja secara bersama-sama dalam kelompok-kelompok kecil untuk memastikan bahwa semua siswa menguasai materi yang diberikan Johnson (2010).

Selain itu, ditemukan pula bahwa selama ini guru belum pernah memperhatikan keterampilan proses sains dan jarang melaksanakan kegiatan praktikum sehingga hasil yang diperoleh kurang maksimal. Oleh karena itu, suatu pembelajaran yang dapat meningkatkan keterampilan proses sains siswa. Keterampilan Proses Sains (KPS) dapat diartikan sebagai wawasan atau anutan pengembangan keterampilan-keterampilan intelektual, sosial, dan fisik yang 
bersumber dari kemampuan-kemampuan mendasar yang pada prinsipnya ialah ada dalam diri siswa.

Salah satu solusi upaya yang dapat dilakukan guru untuk mengatasi masalah-masalah di atas adalah merancang suatu kegiatan pembelajaran yang berbasis penemuan atau inquiry. Menurut Gormally, et.al (2009) bahwa melalui penerapan model pembelajaran inquiry training dapat meningkatkan kemampuan meneliti siswa dan merubah cara belajar siswa yang cenderung kurang aktif dan jarang bertanya. Menurut Vaishnav (2013) bahwa model pembelajaran inquiry trainingjuga dapat meningkatkan kemampuan kognitif siswa.

Penguasaaan dalam membelajarkan IPA akan berhasil jika siswa menyusun sendiri konsep yang mereka butuhkan. Implementasi inquiry training lebih efektif dalam meningkatkan keterampilan proses sains siswa, dan juga hasil belajar siswa, dibandingkan model pembelajaran Direct Instruction. Hal ini karena model pembelajaran inquiry training melibatkan siswa secara aktif menemukan ilmu pengetahuan sendiri. Hal ini didukung oleh teori Suchman (dalam Joyce and Weil, 2011) dimana tujuan umum model pembelajaran inquiry training adalah membantu siswa mengembangkan disiplin intelektual dan keterampilan untuk meningkatkan pertanyaan-pertanyaan dan mencari jawaban yang terpendam dari rasa ingin tahu siswa. Temuan penelitian ini sejalan dengan penelitianyang dilakukan oleh Vaishnav (2013) bahwamodel inquiry training secara signifikan efektif dalampeningkatan hasil belajar kognitif dan afektif sertamengkontribusi sikap peserta didik dibandingkanpendekatan konvensional. Selain itu, Pandey (2011)berdasarkan hasil penelitiannya menyimpulkan bahwa 
menggunakan model pembelajaran inquiry training lebihefektif dibandingkan pembelajaran menggunakankonvensional dilihat dari hasil belajar akademik siswa.

\section{Identifikasi Masalah}

Permasalahan yang dapat diidentifikasi dari latar belakang masalah adalah:

1. Pembelajaran masih bersifat teachercentered.

2. Keterampilan Proses Sains belum diterapkan oleh guru

3. Sikap Ilmiah siswa pada pelajaran IPA masih rendah.

\section{Batasan Masalah}

Berdasarkan identifikasi masalah, maka perlu dilakukan pembatasan masalah yang dirincikan sebagai berikut :

1. Model Pembelajaran yang digunakan adalah model Inquiry Training berbasis kolaboratif.

2. Sikap Ilmiah dilihat pada kemampuan sikap ilmiah tinggi dan sikap ilmiah rendah.

3. Hasil belajar yang akan diukur adalah keterampilan proses sains siswa Kelas IV SD.

\section{Rumusan Masalah}

Berdasarkan batasan masalah, maka dirumuskan permasalahan pada penelitian ini, yaitu:Apakah keterampilan proses sains siswa yang dibelajarkan dengan modelpembelajaran Inquiry Trainingberbasis kolaboratiflebih tinggi daripada siswa yang dibelajarkan dengan modelDirect Instruction?

\section{Tujuan Penelitian}


Berdarkan rumusan masalah, maka tujuan dari penelitian ini, yaitu untuk mengetahui:Pengaruh model pembelajaran Inquiry Trainingberbasis kolaboratif dan model Direct Instructionterhadap keterampilan proses sains.

\section{METODE PENELITIAN}

\section{Lokasi Penelitian}

Penelitian dilaksanakan di SD Methodist 1 Medan.

\section{Populasi dan Sampel Penelitian}

Menurut Sugiyono (2013:80-81) dalam bukunya mengemukakan bahwa "populasi adalah obyek/subyek yang mempunyai kualitas dan karakteristik tertentu yang ditetapkan oleh peneliti untuk dipelajari dan kemudian ditarik kesimpulannya, sedangkan sampel adalah bagian dari jumlah dan karakteristik yang dimiliki oleh populasi tersebut". Populasi dalam penelitian ini adalah seluruh siswa SD Methodist 1 Medan. Sampel dalam penelitian ini diambil secara purposive sampling.

Dengan demikian, sampel pada penelitian ini berjumlahkan 60 orang siswa yang terdistribusi pada dua kelas yaitu kelas IV-A dan IV-B. Setelah dilakukan pengacakan maka terpilih kelas IV-A sebagai kelas eksperimen yang diajarkan dengan model pembelajaran Inquiry Training berbasis kolaboratif dengan jumlah siswa 30 orang, dan kelas IV-B sebagai kelas kontrol yang diajarkan dengan model pembelajaran Direct Instructiondengan jumlah siswa sebanyak 30 orang.

\section{Variabel Penelitian}


Variabel dalam penelitian ini terdiri dari 3 (tiga) jenis, yaitu variabel bebas, variabel moderator dan variabel terikat. Sugiyono (2013:61-62) dalam bukunya mengemukakan bahwa:

Variabel bebas merupakan variabel yang memengaruhi atau yang menjadi sebab perubahannya atau timbulnya variabel dependen (terikat). Variabel terikat merupakan variabel yang dipengaruhi atau yang menjadi akibat, karena adanya variabel bebas. Variabel moderator adalah variabel yang mempengaruhi (memperkuat dan memperlemah) hubungan antara variabel independen dengan dependen.

Adapun yang menjadi variabel bebas pada penelitian ini adalah model pembelajaran Inquiry Training berbasis kolaboratif dan model pembelajaran Direct Instruction. Variabel moderator pada penelitian ini adalah Sikap Ilmiah. Variabel terikat pada penelitian ini adalah keterampilan proses sains.

\section{Instrumen Pengumpulan Data}

Instrumen penelitian adalah alat ukur yang digunakan dalam penelitian. Instrumen dalam penelitian ini adalah tes keterampilan proses sains (KPS), angket sikap ilmiah, dan lembar observasi kegiatan kolaboratif siswa.

\section{Tes Keterampilan Proses Sains}

Instrumen yang digunakan untuk mengukur keterampilan proses sains dalam penelitian ini adalah tes tertulis. Tes disusun dalam bentuk pilihan berganda yang terdiri dari 11 indikator keterampilan proses sains, meliputi: (1) mengamati;
(2) mengelompokkan;
(3) menafsirkan;
(4) meramalkan;
(5) melakukan

komunikasi; (6) mengajukan pertanyaan; (7) mengajukan hipotesis; 
(8)merencanakan percobaan; (9) menggunakan alat; (10) menerapkan konsep; dan (11) melaksanakan percobaan.

\section{Teknik Analisis Data}

\section{Uji Normalitas Data}

Uji normalitas dimaksudkan untuk menetukan normal atau tidaknya distribusi data penelitian, artinya apakah penyebarannya dan populasi bersifat normal. Untuk uji normalitas menggunakan SPSS 22.0 dengan uji Kholmogrov Smirnov, data dilakukan berdistribusi normal apabila nilai probability signifikan $(2-$ sisi) $>$ taraf signifikansi $5 \%$.

\section{Uji Homogenitas Data}

Uji homogenitas bertujuan untuk mengetahui apakah penyebaran data dalam populasi bersifat homogenitas. Uji homogenitas dilakukan dengan uji Ffactorial (factorial F-test), dinyatakan data bersifat homogen apabila nilai probabilitas signifikan (2-sisi) > taraf signifikanisasi 0,05.

\section{Uji Hipotesis Statistik}

Untuk menguji hipotesis penelitian digunakan teknik analisis varians(univariate analysis of variance) dengan bantuan SPSS 16.0 for windows. Kriteria Hipotesis yaitu apabila probabilitas signifikan $<0,05$ maka $\mathrm{H}_{0}$ ditolak

$$
\begin{aligned}
& \text { Ho : } \mu \mathrm{A} 1 \leq \mu \mathrm{A} 2 \\
& \text { На : } \mu \mathrm{A} 1>\mu \mathrm{A} 2
\end{aligned}
$$

Keterangan : 
Ho : $\mu \mathrm{A} 1 \leq \mu \mathrm{A} 2$ :keterampilan proses sains siswa yang dibelajarkan dengan model pembelajaran Inquiry Training berbasis kolaboratif lebih rendah daripada siswa yang dibelajarkan dengan modelDirect Instruction.

Ha : $\mu \mathrm{A} 1>\mu \mathrm{A} 2$ : keterampilan proses sains siswa yang dibelajarkan dengan model pembelajaran Inquiry Training berbasis kolaboratif lebih tinggi daripada siswa yang dibelajarkan dengan modelDirect Instruction.

\section{HASIL PENELITIAN DAN PEMBAHASAN}

\section{Hasil Keterampilan Proses SainsSiswa}

Hasil yang diperoleh dari penelitian ini, meliputi keterampilan proses sains siswa di kelas eksperimen dan kelas kontrol, serta data sikap ilmiah siswa pada mata pelajaran IPA materi sumber daya alam di kelas IV SD Methodist 1 Medan. Data hasil pretes kelas ekperimen yang dibelajarkan dengan model pembelajaran Inquiry Training berbasis Kolaboratif dan kelas kontrol yang dibelajarkan dengan model pembelajaran Direct Instruction.

Tabel Nilai Pretes Keterampilan Proses Sains

\begin{tabular}{llllll}
\hline Kelas Eksperimen & \multicolumn{5}{l}{ Kelas Kontrol } \\
\hline Skor & Frekuensi & $\begin{array}{l}\text { Frekuensi } \\
\text { Relatif }(\boldsymbol{\%})\end{array}$ & Skor & Frekuensi & $\begin{array}{l}\text { Frekuensi } \\
\text { Relatif } \\
(\boldsymbol{\%})\end{array}$ \\
\hline $10-19$ & 1 & 3,3 & $10-19$ & 0 & 0 \\
\hline $20-29$ & 9 & 30,0 & $20-29$ & 14 & 46,7 \\
\hline $30-39$ & 3 & 10,0 & $30-39$ & 4 & 13,3 \\
\hline $40-49$ & 6 & 20,0 & $40-49$ & 6 & 20,0 \\
\hline $50-59$ & 10 & 33,3 & $50-59$ & 5 & 16,7 \\
\hline $60-69$ & 1 & 3,3 & $60-69$ & 1 & 3,3 \\
\hline
\end{tabular}




\begin{tabular}{llllll} 
Total & 30 & 100 & Total & 30 & 100 \\
\hline Rata-rata & $\mathbf{3 9 , 7 0}$ & & Rata-rata & $\mathbf{3 7 , 1 2}$ & \\
\hline
\end{tabular}

Dari Tabel diatas, dapat dilihat bahwa pengetahuan awal siswa terhadap materi sumber daya alam hampir sama, diketahui bahwa rata-rata nilai hasil pretes kelas eksperimen adalah 39,70dan rata-rata hasil pretes kelas kontrol sebesar 37,12 .

Selanjutnya kedua kelompok diberi perlakuan yang berbeda, yaitu kelompok eksperimen dibelajarkan dengan model pembelajaran Inquiry Training berbasis Kolaboratif,sedangkan kelompok kontrol dibelajarkan dengan model pembelajaran Direct Instruction. Pada pertemuan akhir pembelajaran diberikan postes untuk mengetahui hasil keterampilan proses sainsnya. Adapun hasil postes yang dimaksud disajikan pada Tabel berikut ini:

\section{Tabel Nilai Postes Keterampilan Proses Sains}

\begin{tabular}{lllllll}
\hline & Skor & Skor & Jumlah & Rata-rata & \multicolumn{2}{l}{ Simpangan } \\
& Terendah & Tertinggi & Skor & Skor & Baku & \\
\hline Eksperimen & 36,0 & 95,0 & 2417,0 & 80,567 & 12,212 & 149,151 \\
Kontrol & 32,0 & 91,0 & 1919,0 & 63,967 & 15,953 & 254,516 \\
\hline
\end{tabular}

Dari Tabel diatas dapat dilihat bahwa kelompok eksperimen yang dibelajarkan dengan model pembelajaranInquiry Training berbasis kolaboratif memperoleh rata-rata hasil postesnya sebesar 80,567dengan simpangan baku12,2127, sementara kelas kontrol yang dibelajarkan dengan model pembelajaran Direct Instructionmemperoleh rata-rata hasil postesnya sebesar 63,967dengan simpangan baku sebesar 15,9536. Oleh karena itu, maka dapat disimpulkan bahwa rata-rata keterampilan proses sainssiswa kelas eksperimen lebih tinggi dibanding rata-rata keterampilan proses sains kelas kontrol. 
Berdasarkan hasil pretes dan postes dapat diketahui tingkat pemahaman siswa tentang materi sumber daya alam dengan menghitung gain ternormalisasinya.Deskripsi data gain kedua kelompok disajikan pada Tabel berikut ini.

Tabel Data Gain KPS Berdasarkan Model Pembelajaran

\begin{tabular}{lllllll}
\hline & $\begin{array}{l}\text { Skor } \\
\text { Terendah }\end{array}$ & $\begin{array}{l}\text { Skor } \\
\text { Tertinggi }\end{array}$ & $\begin{array}{l}\text { Jumlah } \\
\text { Skor }\end{array}$ & $\begin{array}{l}\text { Rata-rata } \\
\text { Skor }\end{array}$ & $\begin{array}{l}\text { Simpangan } \\
\text { Baku }\end{array}$ & \\
\hline Eksperimen & 0,22 & 0,93 & 20,74 & 0,691 & 0,166 & 0,028 \\
Kontrol & 0,00 & 1,00 & 17,42 & 0,580 & 0,291 & 0,085 \\
\hline
\end{tabular}

Tabel diatas menunjukkan bahwa gain (tingkat pemahaman) siswa pada materi sumber daya alamuntuk kelas eksperimen diperoleh nilai rata-rata sebesar 0,691 (kategori sedang) dengan simpangan baku 0,028, sedangkan kelas kontrol diperoleh rata-rata gain sebesar 0,58 (kategori sedang) dengan simpangan baku 0,085. Persentase tingkat pemahaman siswa berdasarkan model pembelajaran disajikan pada Tabel dibawah ini.

Tabel Persentase Tingkat KPS Berdasarkan Model Pembelajaran

\begin{tabular}{|c|c|c|c|c|c|}
\hline \multirow[t]{2}{*}{ Gain } & \multicolumn{2}{|c|}{$\begin{array}{l}\text { Inquiry Training } \\
\text { berbasis Kolaboratif }\end{array}$} & \multicolumn{2}{|c|}{ Direct Instruction } & \multirow[t]{2}{*}{ Kategori } \\
\hline & $\mathbf{F}$ & $\%$ & $\mathbf{F}$ & $\%$ & \\
\hline $\mathrm{g}<0,3$ & 1 & 3 & 3 & 10 & Rendah \\
\hline $0,3<\mathrm{g} \leq 0,7$ & 15 & 50 & 15 & 50 & Sedang \\
\hline $\mathrm{g}>0,7$ & 14 & 47 & 12 & 40 & Tinggi \\
\hline Jumlah & 30 & 100 & 30 & 100 & \\
\hline
\end{tabular}

Tabel diatas menunjukkan bahwa pada kelompok siswa yang dibelajarkan dengan model pembelajaran Inquiry Training berbasis kolaboratif terdapat 1 orang atau 3\% siswa yang tergolong memiliki tingkat pemahaman rendah, 15 orang atau 50\%siswayangmemiliki tingkatpemahaman sedang, dan 14 orang atau 
47\% siswayangmemiliki tingkatpemahaman tinggi. Sementara itu pada kelompok siswa yang dibelajarkan dengan model Direct Istructionterdapat 3 orang atau 10\% siswa yang memiliki tingkat pemahaman rendah, 15 orang atau 50\% siswa yang tergolong memiliki tingkat pemahaman sedang dan 12 orang atau $40 \%$ siswa yang memiliki tingkat pemahaman tinggi.

Selanjutnya Data hasil penelitian dapat dianalisis dengan uji parametrik, maka perlu dilakukan beberapa uji prasyarat, yaitu uji normalitas untuk melihat sebaran data keterampilan proses sains siswa berdistribusi normal atau tidak danuji homogenitas untuk melihat varians dari kedua kelompok homogen atau tidak. Dalam penelitian ini uji normalitas dan homogenitas dilakukan dengan bantuan SPSS 22.0.

\section{Uji Normalitas Data}

Uji normalitas distribusi sampel dilakukan dengan teknik KolmogorovData dinyatakan berdistribusi normal jika probabilitas atau sig.> 0,05. Hasil perhitungan dengan formula Kolmogorovdengan bantuan SPSS 22.0dapat dilihat pada Tabel berikut :

\section{Tabel Hasil Uji Normalitas Data}

\begin{tabular}{llll} 
Kelas & \multicolumn{4}{l}{ Kolmogorov-Smirnov ${ }^{\mathrm{a}}$} \\
\cline { 2 - 4 } & Statistik & Df & Sig. \\
\hline eksperimen & 0,181 & 30 & 0,130 \\
\hline kontrol & 0,257 & 30 & 0,220 \\
\hline
\end{tabular}

Tabel diatas menunjukkan bahwa data nilai signifikansi Kolmogorofuntuk data preteskelas eksperimen 0,130 lebih besar dari taraf signifikansi 0,05 sehingga 
$\mathrm{H}_{0}$ diterima, dan data nilai signifikansi Kolmogorofuntuk data preteskelas kontrol 0,220 lebih besar dari taraf signifikansi 0,05 sehingga $\mathrm{H}_{0}$ diterima. Sehingga dapat disimpulkan bahwa data pretes pada kelas eksperimen dan kelas kontrol memiliki sebaran data yang berdistribusi normal.

\section{UjiHomogenitas Data}

Pengujian homogenitas dilakukan dengan menggunakan teknik Levene Test atau Uji F dengan bantuan SPSS 22.0 Pengujian homogenitas dilakukan pada data pretes. Data dinyatakanmemiliki varian yang sama (homogen) jika nilaisig> 0,05. Hasil pengujian data disajikan pada Tabel berikut.

\section{Tabel Hasil Uji Homogenitas Data}

\begin{tabular}{llll}
\hline Levene Statistic & $\mathrm{df}_{1}$ & $\mathrm{df}_{2}$ & Sig. \\
\hline 0,011 & 1 & 58 &, 917 \\
\hline
\end{tabular}

Tabel diatas menunjukkan bahwa nilai uji Levene test (Fhitung) adalah 0,011 dengan signifikansi 0,917 (Ftabel $=0,675, \alpha=0,05)$. Data ini menunjukkan bahwa daripengujian homogenitas varians diperoleh Fhitung $(0,011)$ < Ftabel $(0,675)$ serta nilai signifikansi $0,917>0,05$ sehingga dapat disimpulkan bahwa varians kedua kelompok sampel homogen.

\section{PENUTUP}

\section{Kesimpulan}

Berdasarkan hasil penelitian yang telah dikemukakan sebelumnya, maka dapat ditarik kesimpulan bahwa keterampilan proses sains siswa yang dibelajarkan dengan model pembelajaran Inquiry Trainingberbasis kolaboratif lebih tinggi daripada keterampilan proses sains siswa yang dibelajarkan dengan 
modelDirect Instructiondi SD Methodist 1 Medan. Hal tersebut bukan hanya berdasarkan hasil uji hipotesis pertama dan berdasarkan analisis skor keterampilan proses sains tetapi juga berdasarkan pada perbedaan fase pembelajaran, bahwafase-fase model pembelajaran Inquiry Training menciptakan kegiatan ilmiah dalam memperoleh pengetahuan sehingga terlatihlah keterampilan proses sains siswa, sedangkan fase-fase model pembelajaran hanya melatih kognitif siswa. Fase-fase model pembelajaran Inquiry Trainingyaitu: (1) menghadapkan pada masalah; (2) pengumpulan data; (3) mengolah atau memformulasikan suatu penjelasan; dan (4) analisis proses penelitian. Fase-fase model pembelajaran Direct Instructionyaitu: (1) orientasi pembelajaran; (2) penyajian materi; (3)latihan terstruktur; (4) membimbing pelatihan; dan (5) latihan mandiri.

Dari hasil penelitian juga dapat disimpulkan bahwa keterampilan proses sains siswa yang mempunyai sikap ilmiah tinggi lebih tinggi daripada sikap ilmiah rendah. Hal tersebut juga bukan hanya berdasarkan hasil uji hipotesis kedua dan analisis skor keterampilan proses sains tetapi juga berdasarkan tingkat sikap ilmiah itu sendiri. Sikap ilmiah sangat berkaitan dengan keterampilan proses sains, jika sikap ilmiah tinggi maka keterampilan proses sains siswa juga akan tinggi, begitu sebaliknya sehingga keterampilan proses sains yang mempunyai sikap ilmiah tinggi lebih baik daripada sikap ilmiah rendah.

Kesimpulan terakhir yang diperoleh dari hasil penelitian bahwa terdapat interaksi antara model pembelajaran Inquiry Trainingberbasis kolaboratif dan Direct Instructiondengan tingkat sikap ilmiah siswa dalam memengaruhi keterampilan proses sains siswa. Bahkan dari hasil uji lanjutan yaitu uji scheffe 
diperoleh bahwa interaksi yang paling kuat dalam mempengaruhi keterampilan proses sains adalah model pembelajaran Inquiry Training berbasis Kolaboratif dengan sikap ilmiah tinggi. Hal tersebut bukan hanya berdasarkan rerata perbedaan pada uji scheffe tetapi juga karena langkah-langkah model pembelajaran Inquiry Training berbasis Kolaboratif yang lebih sesuai dengan keterampilan proses sains siswa dan didukung juga dengan sikap ilmiah yang tinggi sehingga interaksi ketiganya menjadi sangat kuat.

\section{DAFTAR PUSTAKA}

Azizah, A. Parmin.2012. Inquiry Training untuk Mengembangkan Keterampilan Meneliti Mahasiswa. Unnes Science Education Journal. USEJ 1 (1): 1-11

Departemen Pendidikan Nasional. 2003. Kamus Besar Bahasa Indonesia EdisiKetiga. Jakarta: Balai Pustaka.

Gormally, C., Brickmann, P., B., \& Armstorng, N. Effects of Inquiry-based Learning on Students' Science Literacy Skliis and Confidence. International Journal for The Scholarship of Teaching and Learning. Vol 3 No 2: 1-21

Joyce., Weil. 2011. Models Of Teaching, Edisi Kedelapan. Yogyakarta: Pustaka Belajar.

Halimatus. 2014. Efek Model Pembelajaran Inquiry Training Berbantukan Hand Out dan Sikap Ilmiah Terhadap Kemampuan Siswa Berbasis KPS. Jurnal Pendidikan Fisika. Vol. 3 (3) : 33-39.

Johnson,D.2010. Coborative Learning. Bandung: Nusa Media.

Instrani,P. I. 2015. Ensiklopedi Pendidikan Jilid I. Medan: Media Persada.

Mulyasa, E. 2009. Menjadi Guru Profesional Menciptakan Pembelajaran Kreatif dan Menyenangkan. Bandung.

Purwanto, 2011. Evaluasi Hasil Belajar. Yogyakarta: Pustaka Belajar.

Sardiman, A.M. 2011. Interaksi dan Motivasi Belajar Mengajar. Jakarta: Raja Grafindo Persada.

Sugiyono. 2013. Metode Penelitian Pendidikan Kualitatif, Kuantitatif, dan R\&D. Bandung. Alfabeta. 
Trianto. 2008. Mendesain Model pembelajaran Inovatif Progresif. Jakarta: Kencana Prenada Group.

Vaishnav, R. 2013. Effectiveness of Inquiry Training for Teaching Science.Scholary Research Journal for Interdisiplinary Studies. Vol.1, pp: 1216-1220. 